\title{
THE VULNERABILITY OF LEAFLITTER ANTS TO FOREST DISTURBANCES IN THE ISLAND OF PUERTO RICO, GREATER ANTILLES
}

\author{
La vulnerabilidad de hormigas de la hojarasca a perturbaciones forestales \\ en la isla de Puerto Rico, Antillas Mayores
}

\begin{abstract}
Miguel A. García
Science Application, US Fish and Wildlife Service. 1201 Ceiba st. San Juan PR 00926.Center for Applied Tropical Ecology and Conservation. University of Puerto Rico, Río Piedras Campus. P.O. Box 23360 San Juan PR 009313360. isladelamona@gmail.com.
\end{abstract}

\begin{abstract}
Reduced biodiversity and high number of endemics characterize island ecosystems. Island natives and endemics are considered more vulnerable than continental species to exotic species invasions and habitat changes. The effect of replacing a native forest by an exotic wood plantation was studied on the assemblage of native and endemic ant species. The main hypothesis was that endemic and native ant species were more vulnerable to habitat changes than the exotic ant species. Nevertheless, it was found that native ants were more numerous and specious in both native and exotic plantations. Also, high numbers of two endemic ants were detected within exotic plantations, while only one exotic ant Hypoponera opacipeps was relatively abundant, particularly on native forest. In conclusion, exotic ant species did not dominate the communities studied nor the native and endemic ant assemblages seemed to be affected negatively by the forest replacement.
\end{abstract}

Keywords: ants, vulnerability, native, exotic, plantation, island, disturbance, Mona Island, Greater Antilles.

\section{RESUMEN}

Una biodiversidad reducida y un número alto de endémicos caracterizan los ecosistemas insulares. Especies nativas y endémicas de islas son consideradas más vulnerables que las especies continentales a la invasión de especies exóticas y a cambios en el hábitat. El efecto de reemplazar bosque nativos por plantaciones exóticas de especies maderables fue estudiado en el montaje de especies nativas y endémicas de hormigas. La hipótesis principal consistió en que las especies endémicas y nativas eran más vulnerables a cambios en el hábitat que las especies de hormigas exóticas. Sin embargo, se encontró que las hormigas nativas fueron más numerosas y diversas, tanto en bosques nativos como en las plantaciones exóticas. También apareció un número alto de dos especies endémicas dentro de plantaciones de exóticas, mientras sólamente una especie de hormiga exótica Hypoponera opacipeps fue relativamente abundante, particularmente en bosque nativo. En conclusión, las especies de hormigas exóticas no dominaron las comunidades estudiadas, ni tampoco parecieron impactarse negativamente las especies nativas y endémicas por el reemplazo del bosque.

Palabras clave: hormigas, vulnerabilidad, nativa, exótica, plantación, islas, perturbación, Isla de Mona, Antillas Mayores. 


\section{INTRODUCTION}

The reduced number of species found in insular habitats is one of the most perceptible differences between island and mainland biotas (Heany, 1986; Vitousek, 1988; Adsersen, 1995; Simberloff, 1995). But, tropical islands usually exhibit higher numbers of endemic species than tropical and temperate mainlands (Vitousek, 1988). The vanishing of an insular species would probably represent a worldwide net loss in biodiversity, whereas the same event in a mainland habitat would only cause a reduction in the species' distribution. Hence, it is important to consider endemicity as well as biodiversity when studying island biotas or ecosystems (Platnick, 1992).

The major causes of extinctions are habitat loss, the introduction of exotic species (i.e., diseases, predators and competitors; Walker and Steffen, 1997), and uncontrolled exploitation of resources, e.g., hunting, fishing, timber, etc. (Myers, 1989; Fordham and Brook, 2010). Insular species exhibit greater extinction rates, and are more susceptible to environmental stress than their mainland counterparts (Vitousek, 1988; Vitousek et al., 1995; Sadler, 1999; Blackburn et al., 2004; Sodhi et al., 2004). This higher vulnerability in insular biotas has been explained by their low population numbers, reduced genetic diversity, constrained geographical range (Vitousek, 1988; Adsersen, 1995; Wetzel et al., 2013), and limited migration (Foufopoulus and Ives, 1999). Within island biotas, endemic organisms are considered more vulnerable than native or cosmopolitan species (Silva-Taboada, 1992; Adsersen, 1995), and rare endemic species are two times more prone to decline in abundance due to alien species than rare native species (Adsersen, 1989, 1995). The chances of a successful invasion of an alien species and the negative impact on insular biotas seem to be more related to the absence of certain functional groups or open niches (Beisner et al., 2006). For example, terrestrial carnivore mammals are missing from many islands, thus there is a predisposition for this group to survive and impact negatively these ecosystems after invading since the local biota have evolved without the presence of this component of the trophic web (Simberloff, 1995). However, other investigations have supported that introduced species are often superior competitors because they have evolved in more competitive environments (Williamson, 1989; Callaway and Aschehoug, 2000) or lack natural enemies in the new areas (Siemann and Rogers, 2001), backing up the hypotheses related to the prevalence of particular biological traits such as fragility or unaggresiveness of the insular biotas.

Recent studies have documented that replacing nature forest by exotic tree plantations have impacted negatively native dragonflies associated to the native forest (Renner et al., 2016; Dalzochio et al., 2018) in Brazil. But, the presumed vulnerability of insular biotas for habitat modification (Foufopolous and Ives, 1999) requires adequate testing. Particularly, timely research has to assess if endemic species are more vulnerable than natives to habitat changes and if natives are more vulnerable than cosmopolitan or exotic species.

The Caribbean is considered one of the biodiversity hotspots in the world (Cincotta and Engelman, 2000; Myers et al., 2000). These islands have also suffered great anthropogenic disturbances, including deforestation and the introduction of exotic plants and animals (Ambio, 1981; Gajraj, 1981; Lugo et al., 1999). Puerto Rico, as the other islands of the West Indies, harbors large percentages of native and endemic species (Wiley and Vilella, 1998). This island experienced during the 1930's and 1940's the substitution of patches of native forest by plantations of several tree species for timber purposes (Wadsworth, 1973, 1990). The forestry activity was later terminated, leaving abandoned several plantations of exotic timber species like Dominican Mahogany (Swietenia mahogany), Australian Pine (Casuarina equisetifolia) and Caribbean Pine (Pinus caribaea) (Wadsworth, 1973, 1990; Birdsey and Weaver, 1982). The impact of these alterations on the local fauna has not been adequately studied, although, differences in forest birds have been documented (Collazo and Bonilla-Martínez, 1988). 
My main objective was to investigated the long lasting effect of the wood plantations on the leaflitter ant community. Ants were selected for this study because: (1) they are sensitive to habitat modifications even at small scales (Folgarait, 1998; Abensperg-Traun and Smith, 1999; Brühl et al., 2003), and (2) their taxonomy and biogeographical distribution are relatively well known in Puerto Rico. Therefore, it is possible to identify if the species collected is endemic, native, or exotic to the studied habitats. It was also important to assess if the establishment of exotic wood plantations has impacted more the endemic and native ants than the cosmopolitan and exotics. This impact could be direct due higher tolerance of exotic species to some of the simplified conditions found on the plantations, like the reduced availability of leaflitter habitats. In fact, exotic ants exhibit several traits that facilitate colonizing and establishing into new environments. For example, they tend to be generalists in term of nesting and diet, most exhibit polygyny; colonial budding and reduced intraspecific aggresivity (Hölldobler and Wilson, 1990; Hollway et al., 2002b). Exotic ants prevalence could be also attained indirectly when the modification in the habitat facilitates the establishment of invasive ant species (Hollway et al., 2002a) or through aggressive interspecific interactions. It has been documented that invasive ant species outcompete and displace the native ant assemblages causing dramatic reductions in the local ant species richness (see Clark et al., 1982; Porter and Savignano, 1990; Williams, 1994; Hollway, 1998; Suárez et al., 1998; Hoffmann et al., 1999; Wojcik et al., 2001; Sanders and Barton, 2001; Hollway et al., 2002b; Armbrecht and Ulloa-Chacón, 2003). Several of these invasive ants have become established in Puerto Rico (Torres, 1984a) and are found throughout the island.

\section{MATERIALS AND METHODS}

Study Sites. This study was conducted at three forests in Puerto Rico-Guánica Forest, Mona Island, and Carite Forest. Guánica and Carite natural reserves are found in the main island. Mona Island is $42 \mathrm{~km}$ west of Puerto Rico, and has never been connected to it (Wiley and Vilella, 1998). Guánica and Mona Island are considered Subtropical Dry Forests, while CariteForest is composed mostly of Subtropical Wet Forest (Ewel and Whitmore, 1973; Birdsey and Weaver, 1982). Guánica has plantations of mahogany, Swietenia mahogany (Wadsworth, 1990), while Mona Island has mahogany and Australian pine (Casuarina equisetifolia) plantations (Cintrón and Rogers, 1991). Caribbean pine (Pinus caribaea) plantations are found in Carite (Department of Natural Resources, 1974). All these plantations and native forests offer a great opportunity to study the effects of the replacement of the native vegetation on the local biotas since they have been left undisturbed for more than 20 years (Wadsworth, 1973, 1990).

Ants were collected during the dry (February-April) and wet seasons (September-November) of 1997 and 1998. Two areas were selected within each natural forest or plantation type, and I layed down, 2-40 meter long transects within each area. Five pitfall traps $(500 \mathrm{ml})$ were set at ten meter intervals along each transect. Pitfall traps were flushed with the ground level, and half filled each one with a hypersaline solution of water and soap. All traps were removed after five days and filled with 70\% ethyl alcohol. Then, they were taken to the Department of Natural and Environmental Resources (DNER) and the University of Puerto Rico (UPR) facilities, where all were cleaned of debris and soil.

Ants were stored in vials with 70\% ethyl alcohol, and later sorted and identified to species level. Ants were posteriorly classified as endemic, native, or exotic; considering endemic all the species limited only to the Puerto Rican bank, native all the species exhibiting Greater Antilles distribution, and exotic all the species outside this range (Snelling and Torres, unpublished data). 


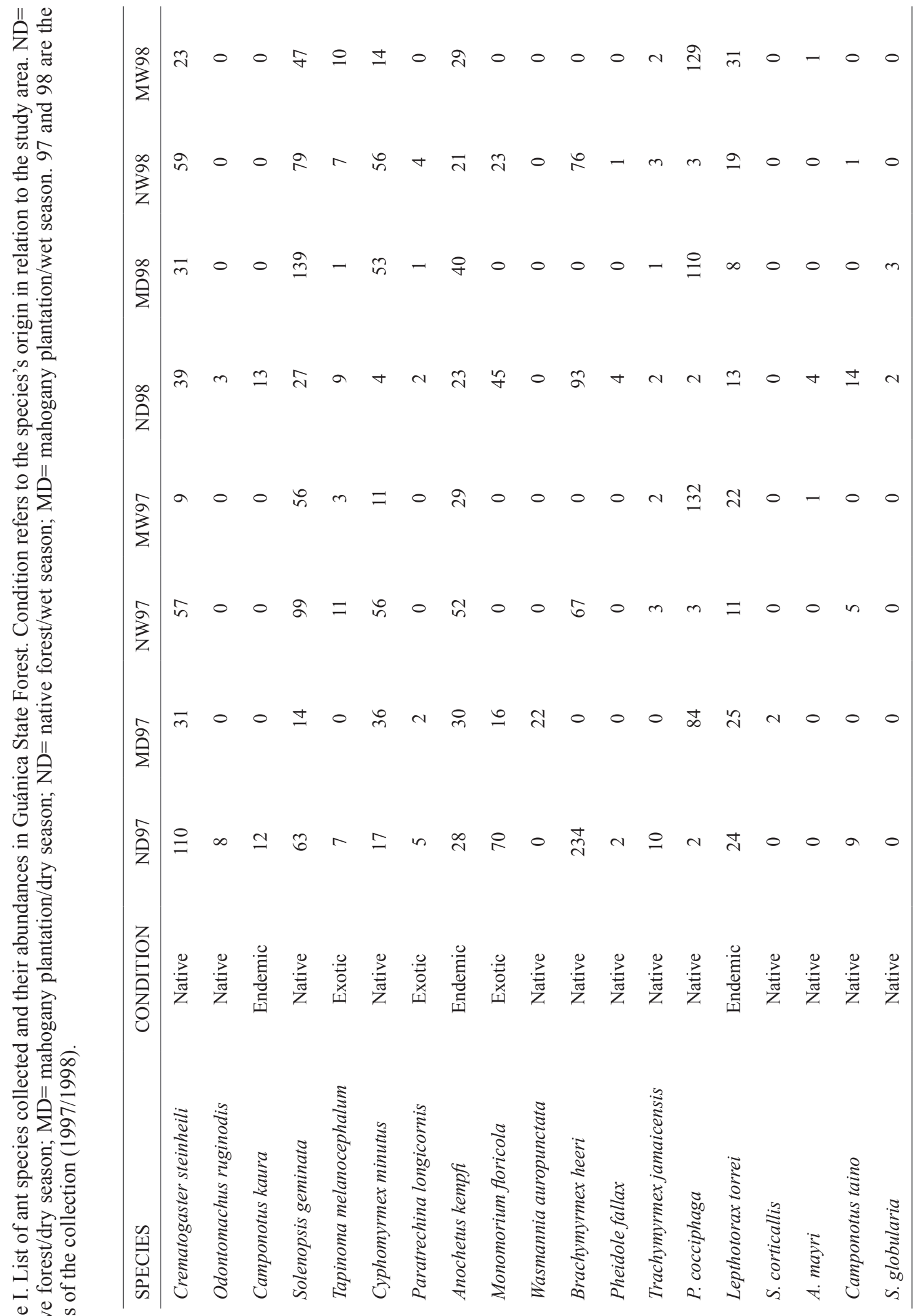

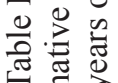


光宫

ฮี่

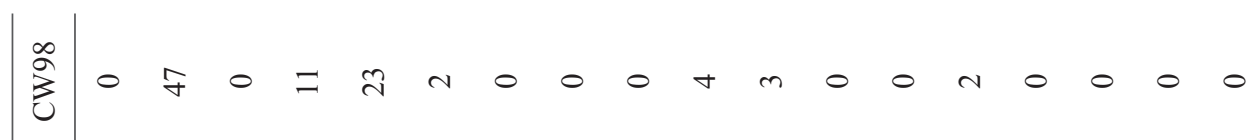

总蕗

톨

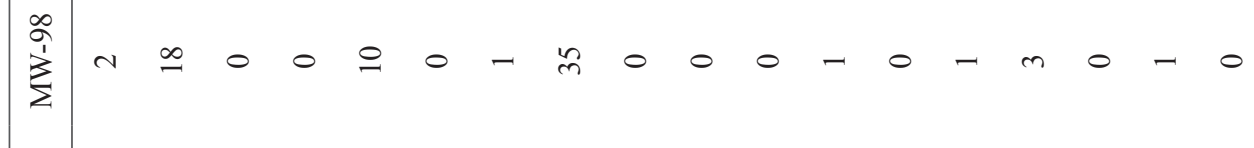

을

总

혼

$\Xi$ :

.

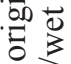

is

氖 晜

की

业

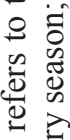

드을

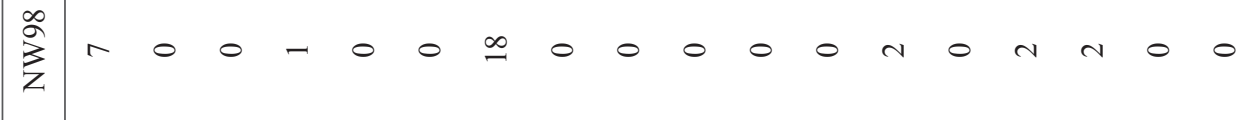

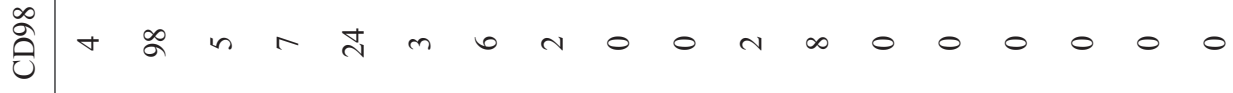

记 莺

药

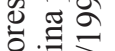

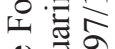

䒿芯

施

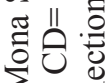

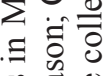

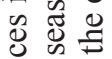

츤

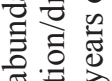

휴류

穸京

స్

웡 월

豞 ล̃

¿

该

की क

芯导

눙클

步莺

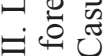

$0 \geqslant 11$

恶离

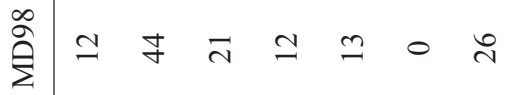

会

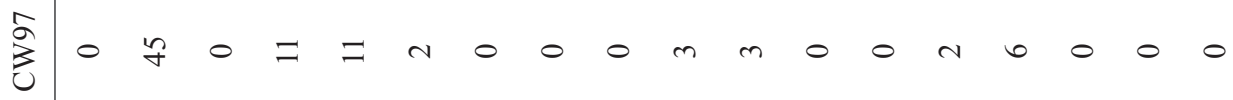

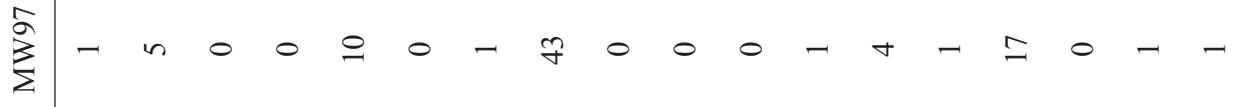

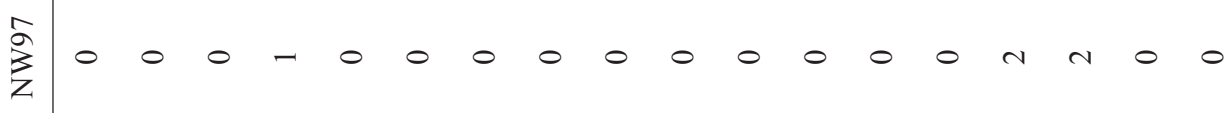

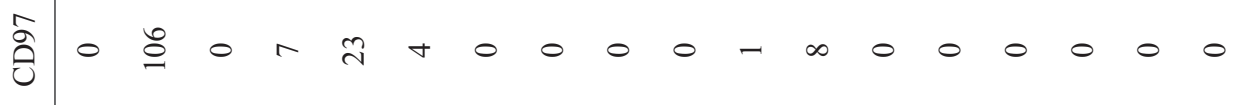

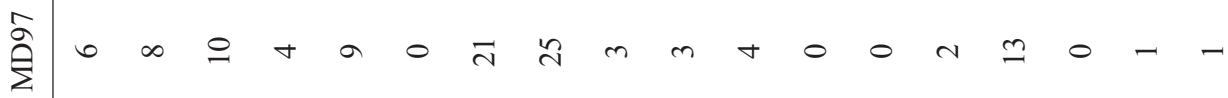

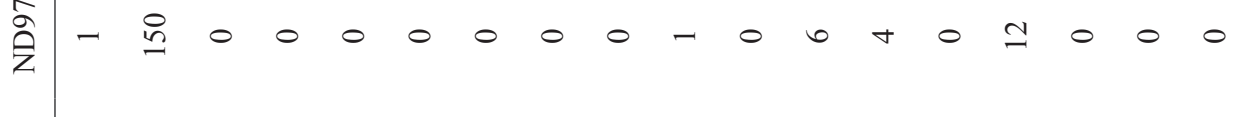

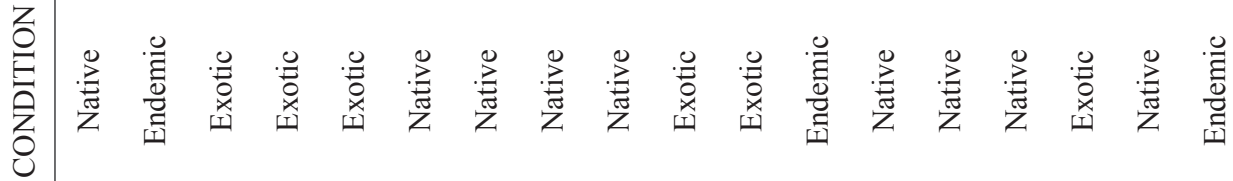

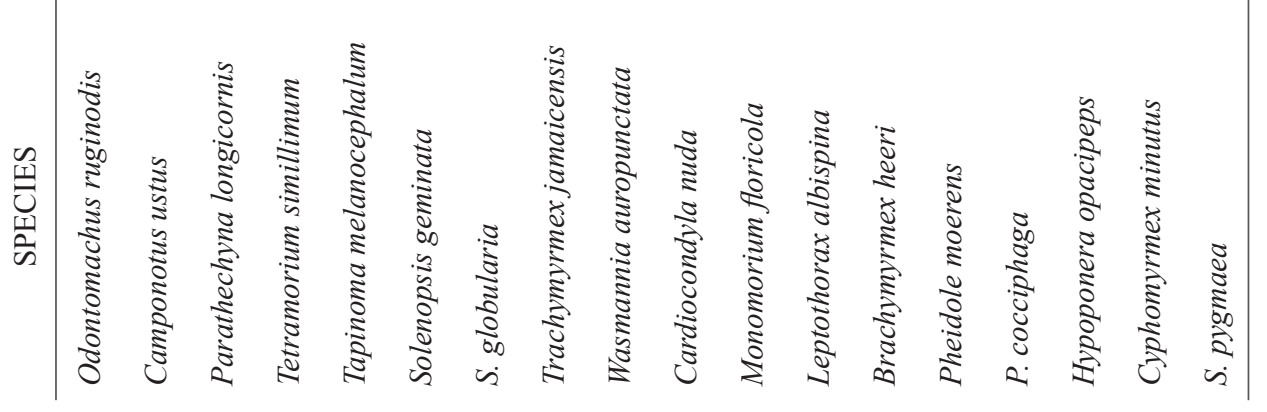


Statistical Analysis. Data were pooled by year and season to increase sample size. Bray-Curtis ordination (Bray and Curtis, 1957) was used to determine similarity patterns between the endemic, native and exotic ant species assemblages and the forest types (i.e. exotic plantation or native forest). Ordination methods establish species or samples patterns (Krebs, 1989) and Bray-Curtis has shown to perform with robustness (Beal, 1984; McCune and Grace, 2002). Ordination values and figures were obtained using PCORD 4.0 (McCune and Grace, 2002).

The abundance of native, exotic and endemic ant species among the native forest and the exotic plantations was analyzed using a one sample chi square. This comparison was done first by pooling all the abundances, and then by species to eliminate any bias caused by a dominant ant in terms of number of individuals. The number of individual was added for each forest condition, but used the mean value when the comparison was unbalanced. For example, the species was found on two exotic plantations but only once within the native forest. The analysis was not performed on species that were absent in one of the two forest condition considered. All the statistical analyses were made using SPSS 9.0. An alpha $(\alpha)$ value of 0.05 was employed to establish statistical significance. All mean values are provided with their corresponding standard error unless otherwise stated. All plots were generated using Sigmaplot 2001 for Windows (version 7.0).

\section{RESULTS}

Several species showed specificity for a particular forest type. In Guánica, Camponotus kaura, C. taino, Odontomachus ruginodis and Brachymyrmex heeri were found exclusively on the native forest (Table I). Conversely, Wasmannia auropunctata was collected only in the mahogany plantation (Table I) In Mona, Solenopsis pygmaea and Hypoponera opacipeps were trapped solely within the native forest, whereas Trachymyrmex jamaicensis was collected exclusively in the mahogany plantation (Table II). Mycocepurus smithi and Hypoponera opacipeps were captured always within the Carite native forest (Table III). Likewise, Anochetus mayri and Strumigenys rogeri were found only associated with the Caribbean pine plantation (Table III).

A total of 30 ant species in all the study areas. Of these six were endemics, 17 natives and seven exotics (Table I-III). Guánica and Mona exhibited the same number of endemic ant species (3) and they were absent from Carite. Guánica showed the highest number of native species (13) while Carite exhibited the lowest (7). Mona had the highest number of exotic (6) whereas only two were found in Carite and Guánica.

In Guánica, the percentage of endemic ants within the native forest $(50.1 \%)$ and the mahogany plantation (49.9\%) were almost identical (Fig. 1). Therefore, the abundance of endemic ants was not significantly different between these two habitats (Table IV). Native ant percentages differed between the native forest $(56.2 \%)$ and the mahogany $(43.8 \%)$ plantation (Fig. 1). In fact, their respective abundances showed significant statistical differences (Table IV). Exotic ants exhibited very dissimilar percentages when comparing the native forest $(85 \%)$ with the mahogany (15\%) plantation (Fig. 1), and their abundances were significantly different between the native forest and the mahogany plantation (Table I).

The proportions (\%) of endemic, native and exotic ants inhabiting the native forest and the exotic plantations varied considerably in Mona Island (Fig. 2). The percentage of endemic ants differed among the native forest $(35.7 \%)$, the mahogany $(13.2 \%)$ and the Casuarina $(51.1 \%)$ plantation (Fig. 2). Endemic ants were significantly more numerous in the Casuarina plantation, followed by the native forest and the mahogany plantation (Table IV). A different pattern was 
observed for the native ant species (Fig. 2). Here, the percentage of native ants found in the natural forest, the mahogany and the Casuarina plantations were $16.6 \%, 73.7 \%$ and $9.7 \%$, respectively (Fig. 2). The abundance of native species was significantly different (Table IV). The Casuarina plantation (55\%) showed the highest percentage of exotic species, followed by the mahogany plantation (40.6\%) and the native (4.4\%) forest (Fig. 2). The number of exotic ant individuals varied significantly between the native forest, the mahogany and the Casuarina plantation (Table IV).

In Carite, endemic ants were not present. The percentage of native ant species was higher in the native forest $(59 \%)$ than in the Caribbean pine (41\%) plantation (Fig. 3). Thus, I found significant differences in the number of native species collected in the native forest and the Caribbean pine plantation (Table IV). A higher percentage of exotic species was found in the native forest (84.9\%) than in the Caribbean pine (15.1\%) plantation (Fig. 3). The exotic ants were significantly more abundant in the native forest than in the Caribbean pine plantation (Table IV).

Three endemic ant species were more abundant in the native forest and three showed higher abundances in the exotic plantation but these patterns were not significantly different (Table V). I collected more individuals of nine native species in the native forest, whereas eight species were more numerous, two of them significantly, in the exotic plantation (Table V). Of the seven exotic species, five were more numerous on the exotic plantation while two were more abundant in the native forest (Table V). This comparison was statistically significant twice for the exotic plantation and once for the native forest (Table V).

The endemic ant species assemblages were extremely similar (i.e.overlapping symbols) for the native forest (GN) and the exotic plantation (GM) (i.e. mahogany) in Guánica (Fig. 4). In Mona, the endemic ant assemblages (MN;MM;MC) differed among the different systems (discernible symbols separation) (Fig. 4A). But, the endemic ant composition found in the native forest and the Casuarina plantation exhibited higher similarity (closer symbols distance) between them that with the mahogany assemblage (Fig. 4A). The native ant species assemblages found in the native forest and the exotic plantations in Guánica, Mona and Carite were not very similar (Fig. 4B). But, excepting the mahogany plantation in Mona Island, the other assemblages exhibited a certain degree of similarity within each study area (Fig. 4B). Again, the native species composition was more similar between the native forest and the Casuarina plantation in Mona (Fig. 4B). The exotic ant species assemblages were very similar between the native forest and the mahogany plantation in Guánica (Fig. 4C). There is more resemblance between the exotic ants species found in the two exotic plantations in Mona, than with the native forest (Fig. 4C). The exotic ant species composition found in the native forest and the exotic plantation in Carite were very different (Fig. 4C). 


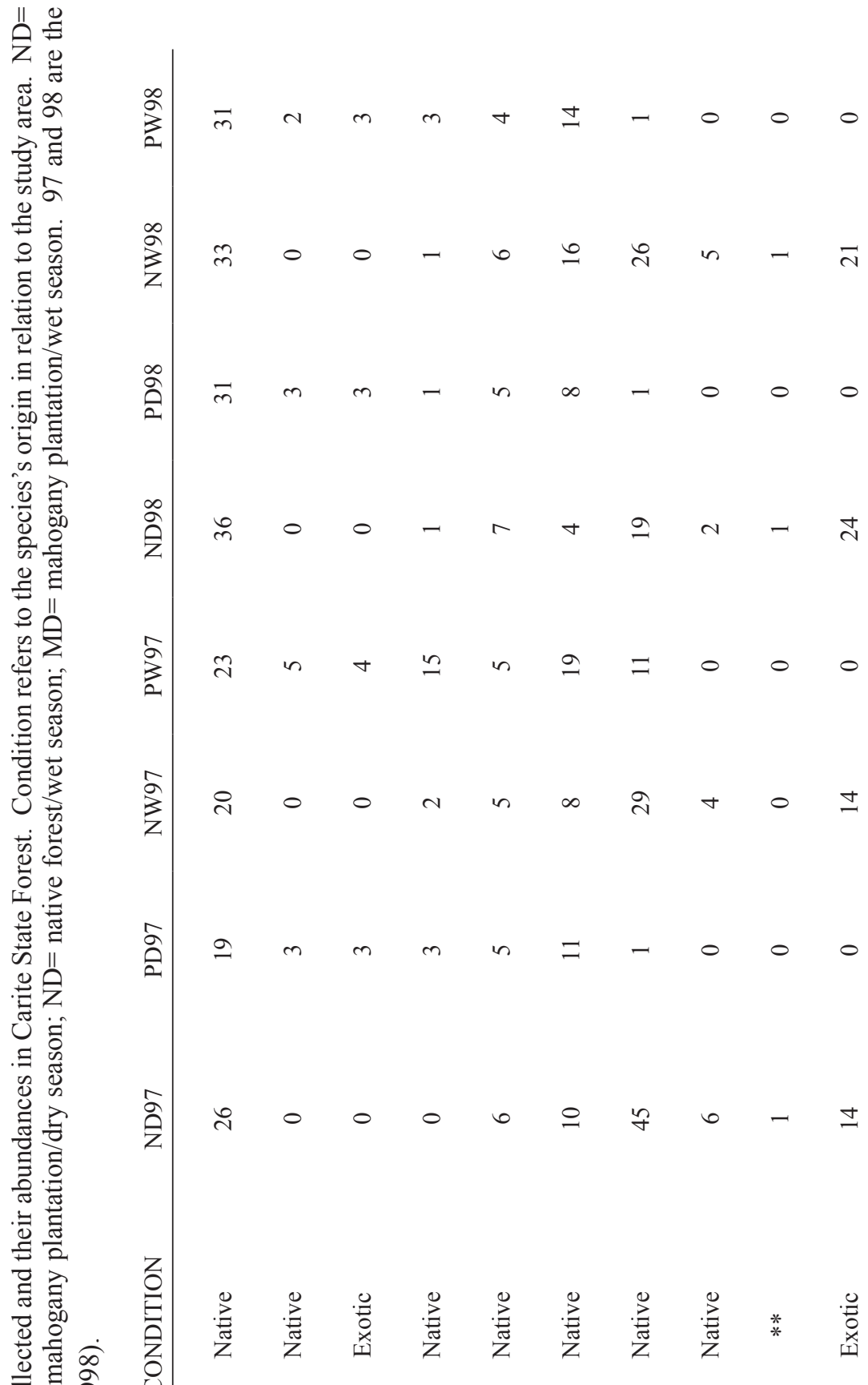




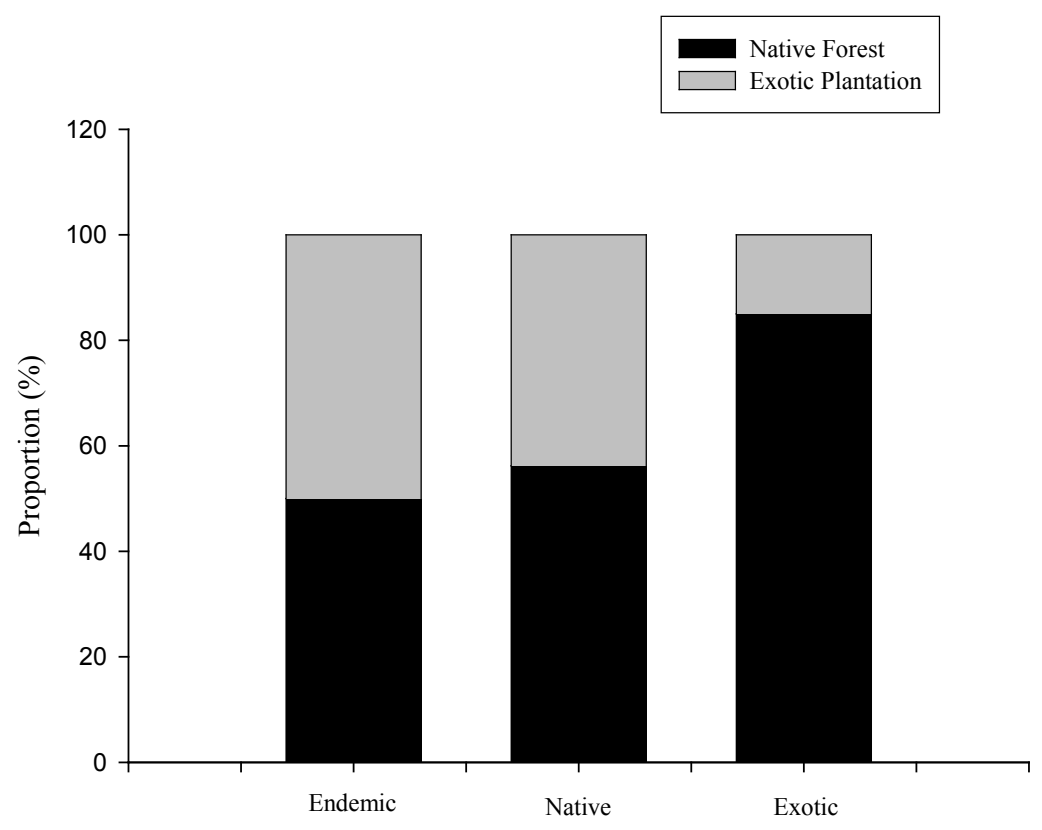

Figure 1. Proportion of endemic, native and exotic ant species collected in the native forest and exotic plantation found in Guánica Forest.

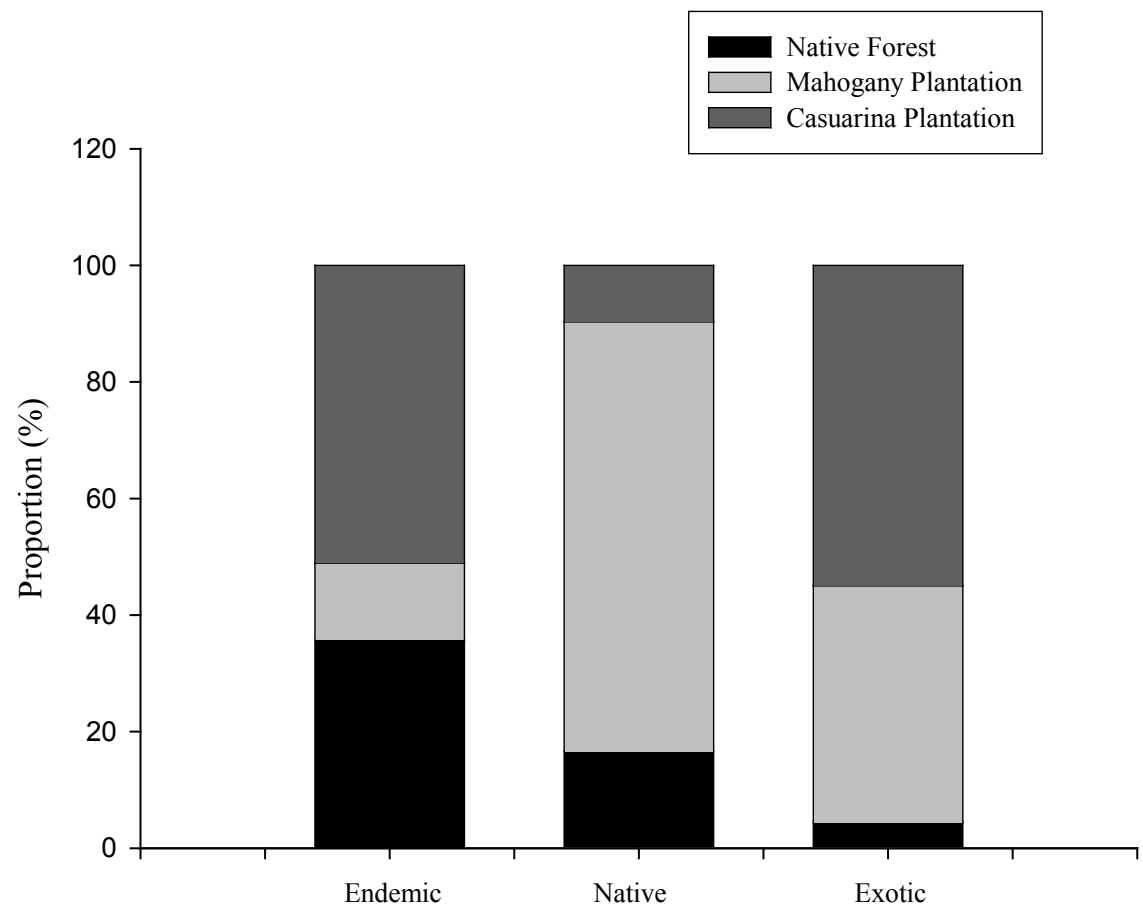

Figure 2. Proportion of endemic, native and exotic ant species collected in the native forest and the exotic plantations found in Mona Forest. 


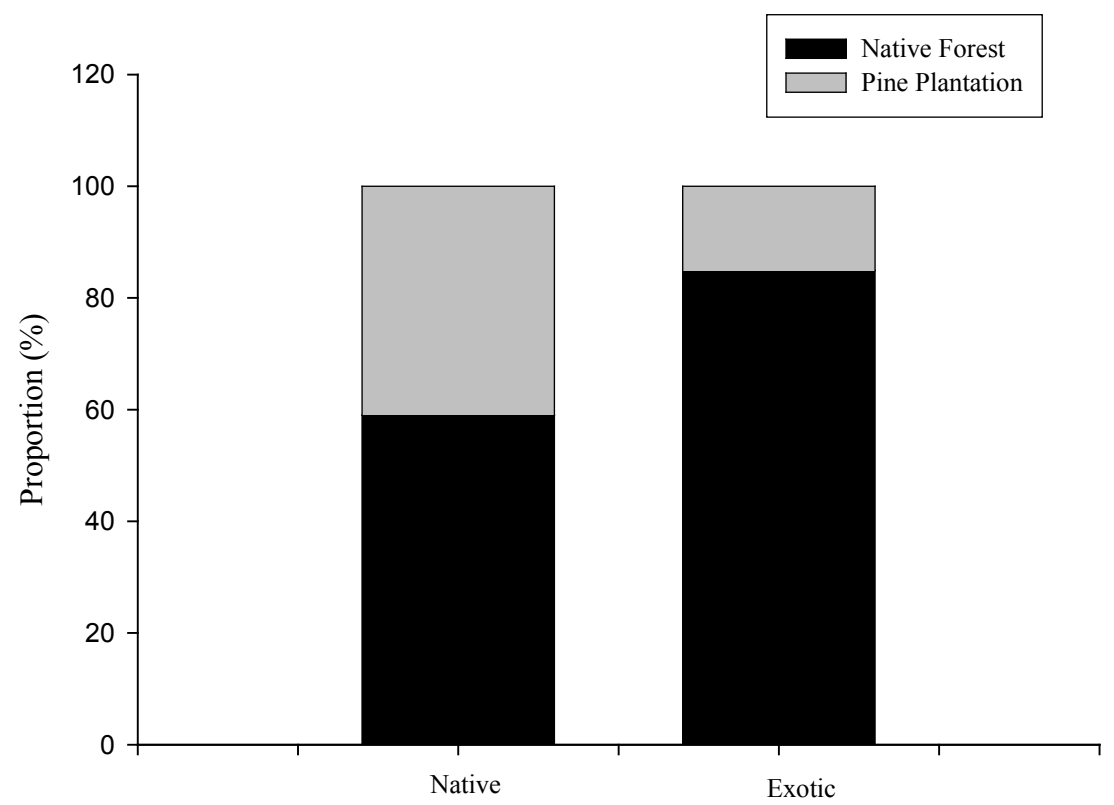

Figure 3. Proportion of endemic, native and exotic ant species collected in the native forest and the exotic plantation found in Carite Forest.

Table IV. Comparison of the ant assemblages between the native forest and the exotic plantation. Guánica and Carite has only one exotic plantation (mahogany) while Mona has two (mahogany/Casuarina). Condition refers to the ant's group considered. Significant comparisons are identified using *

\begin{tabular}{llcccc}
\hline Site & Condition & \multicolumn{2}{c}{ Individuals $(\#)$} & Chi Square & P \\
\hline \multirow{2}{*}{ Guánica } & Endemic & Native Forest & Exotic Plantation & & \\
\cline { 2 - 3 } Guánica & Native & 216 & 214 & 0.009 & 0.923 \\
Guánica & Exotic & 1222 & 951 & 33.79 & $<\mathbf{0 . 0 0 1 *}$ \\
Mona & Endemic & 172 & 30 & 99.82 & $<\mathbf{0 . 0 0 1 *}$ \\
Mona & Native & 218 & $80 / 312$ & 133.94 & $<\mathbf{0 . 0 0 1 *}$ \\
Mona & Exotic & 11 & $252 / 33$ & 253.105 & $<\mathbf{0 . 0 0 1 *}$ \\
Carite & Native & 317 & $102 / 138$ & 102.414 & $<\mathbf{0 . 0 0 1 *}$ \\
Carite & Exotic & 224 & 15.987 & $<\mathbf{0 . 0 0 1 *}$ \\
& & 73 & 13 & 41.86 & $<\mathbf{0 . 0 0 1 *}$ \\
\hline
\end{tabular}


A

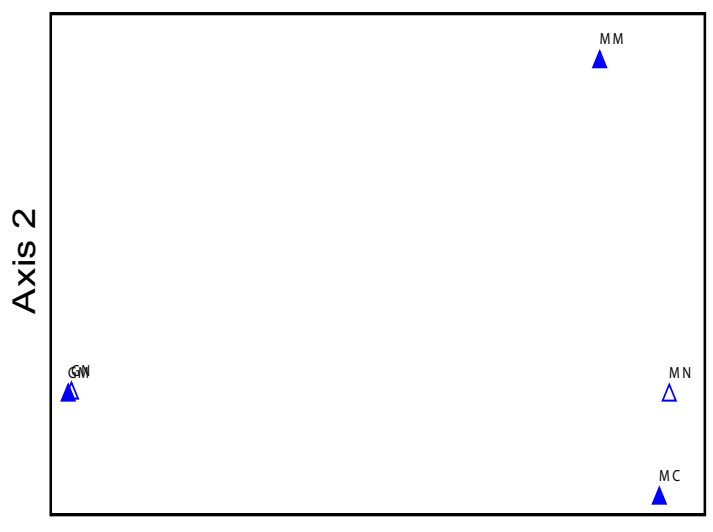

$\triangle$ Native Forest

\ Exotic Plantation

B

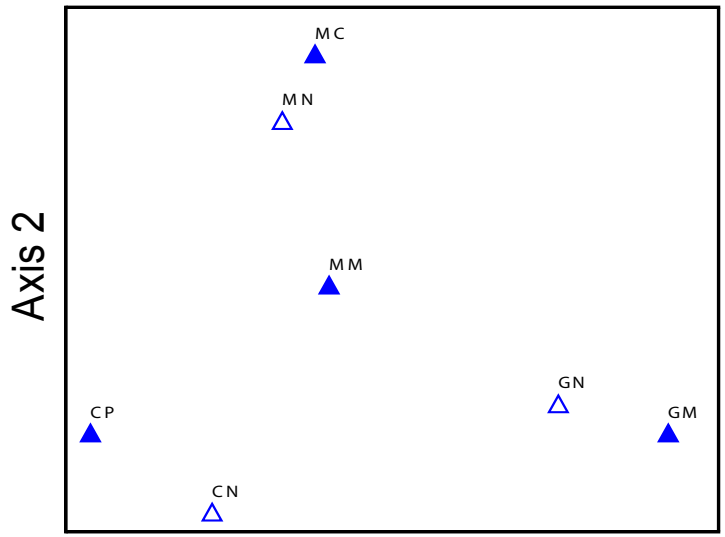

$\triangle$ Native Forest

- Exotic Plantati

Axis 1

C

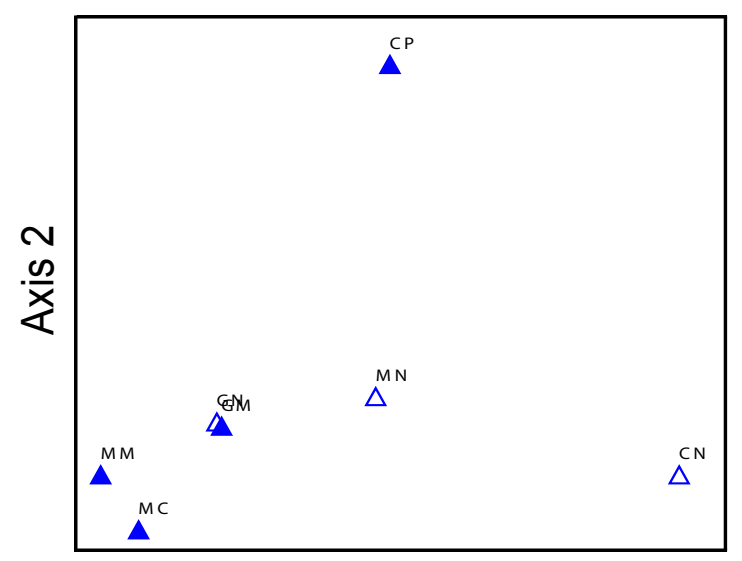

$\Delta$ Native Forest

- Exotic Plantatio

Axis 1

Figure 4. Bray-Curtis ordination showing the endemic (A), native (B) and the exotic (C) ant species composition associated with the native forest and the exotic plantation. The first letter of each symbol represents the area (e.g. Guánica) and the second letter the forest type (e.g. native, mahogany, pine). Similarity is proportional to distance (e.g. closer symbols indicate more resemblance). 
Table V. Comparison of the number of ants by condition between the native forest and the exotic plantation. Guánica and Carite has only exotic plantations of mahogany and Caribbean pine, respectively. Mona has exotic plantations of mahogany and Casuarina. Significant comparisons are identified using *

\begin{tabular}{|c|c|c|c|c|c|}
\hline Species & Condition & Native & Plantation & Chi Square & $\mathrm{P}$ \\
\hline Crematogaster steinheili & Native & 265 & 94 & 81.45 & $<0.001 *$ \\
\hline Odontomachus ruginodis & Native & 18 & 25 & 1.14 & 0.286 \\
\hline Camponotus kaura & Endemic & 25 & 0 & --- & --- \\
\hline Solenopsis geminata & Native & 401 & 285 & 21.14 & $<0.001 *$ \\
\hline Tapinoma melanocephalum & Exotic & 34 & 45 & 1.8 & $<0.180$ \\
\hline Cyphomyrmex minutus & Native & 133 & 58 & 28.521 & $<0.001 *$ \\
\hline Paratrechina longicornis & Exotic & 11 & 13 & 0.167 & 0.683 \\
\hline Anochetus kempfi & Endemic & 124 & 128 & 0.063 & 0.801 \\
\hline Monomorium floricola & Exotic & 138 & 10 & 108.25 & $<0.001 *$ \\
\hline Wasmania auropunctata & Native & 0 & 29 & --- & --- \\
\hline Brachymyrmex heeri & Native & 160.6 & 140 & 123.480 & $<0.001 *$ \\
\hline Pheidole fallax & Native & 7 & 0 & --- & --- \\
\hline Trachymyrmex jamaicensis & Native & 18 & 51 & 15.783 & $<0.001 *$ \\
\hline Pheiodole cocciphaga & Native & 10 & 455 & 425.86 & $<0.001 *$ \\
\hline Leptothorax torrei & Endemic & 67 & 86 & 2.359 & 0.125 \\
\hline Camponotus ustus & Endemic & 206 & 185 & 0.923 & 0.337 \\
\hline Solenopsis corticallis & Native & 0 & 2 & --- & --- \\
\hline Anochetus mayri & Native & 6 & 13 & 2.579 & 0.108 \\
\hline Solenopsis globularia & Native & 10 & 19 & 2.793 & 0.095 \\
\hline Camponotus taino & Native & 29 & 0 & --- & --- \\
\hline Solenopsis pygmaea & Endemic & 0 & 3 & --- & --- \\
\hline Tetramorium simillimum & Exotic & 5 & 26 & 14.226 & $<0.001 *$ \\
\hline Cardiocondyla nuda & Exotic & 2 & 6 & 2.778 & 0.096 \\
\hline Leptothorax albispina & Endemic & 12 & 9 & 0.429 & 0.513 \\
\hline Pheidole moerens & Native & 65 & 51 & 1.661 & 0.197 \\
\hline Hypoponera opacipeps & Exotic & 77 & 0 & --- & --- \\
\hline Strumigenys rogeri & Exotic & 0 & 13 & --- & --- \\
\hline Linephitema melleum & Native & 24 & 19 & 0.581 & 0.446 \\
\hline Paratrechina steinheili & Native & 38 & 52 & 2.178 & 0.140 \\
\hline Mycocepurus smithi & Native & 17 & 0 & --- & --- \\
\hline
\end{tabular}




\section{DISCUSSION}

In this research, contrary to my predictions (1) native ant species dominated in terms of number and species in both the native forests and the exotic plantations, and (2) exotic species did not prevail on any of the ecological systems studied. Interestingly, it has been documented that some invasive species not always become dominant within natural protected areas (Gallardo et al., 2017) since the condition encounter by the invasive specie are not always favorable for them (Martin et al., 2009). Despite the aforementioned overall pattern, natives like Mycocepurus smithi, W. auropunctata, and Anochetus mayri were found exclusively in exotic plantations. The endemic $S$. pygmaea was extremely rare (three individuals), but it was found only associated with native forest. Other endemics like Camponotus ustus and Anochetus kempfi were relatively numerous. However, against mine prediction, their numbers were similar in the native forest and the exotic plantation. I did not find endemic ants in Carite, probably due to the sampling method since endemics have been previously sampled in this forest.

The exotic Hypoponera opacipeps was found exclusively in native forest. Monomorium floricola was the only relatively common exotic ant, especially in Guánica. Nevertheless, it was more abundant in the native forest than in the exotic plantation, a pattern opposed to my hypothesis. This species is also considered a tramp species (Passera, 1994), characterized among other things by being dispersed and living closely associated with humans (Hölldobler and Wilson, 1990; Passera, 1994). Both, the native forest and the exotic plantation are surrounded by dirt roads, and are within $2 \mathrm{~km}$ from the forest administrative office and the visitor center. Thus, there is not a conclusive explanation to account for its scarcity within the exotic plantation., and any further consideration lays beyond the scope of this research.

On this study, it is important to consider that the exotic ants have probably arrived to Puerto Rico before the exotic wood plantations. These plantations were established during the first 50 years of the last century (Wadsworth, 1973, 1990). The native forest and the exotic plantations found in Guánica and Carite shared many endemic and exotic ant species. Nevertheless, the endemic, native and exotic ant assemblages found in the native forest and the exotic plantation in Mona, are composed by different ants species. Particularly, the endemic and natives species collected in the mahogany plantation.

Ant invasions have had major economical impacts (Pimentel et al., 2000; Holway, 2002) and have also caused the displacement of native ant communities (Hölldobler and Wilson, 1990; Porter and Savignano, 1990; Wojcik et al., 2001; Williams, 1994; Holway et al., 2002b) and to other insect species (Wagner and Van Driesche, 2010). W. auropuctata and Solenopsis geminata are considered among the six most damaging invasive ants in the world (Holway et al., 2002a), they are native to Puerto Rico. In this study, while $S$. geminata was the most abundant ant species, particularly in Guánica and on the native forest in Carite, it was scarce in Mona. S. geminata is an opportunistic and ubiquitous species that subdues the majority of the Puerto Rican ants under all environmental conditions (Torres, 1984a). The other species, W. auropunctata was rare elsewhere. Nevertheless, it has been well documented how $W$. auropunctata displaces local ant assemblages, either as a native or invasive species (Clark et al., 1982; Lubin, 1984; Armbrecht and Ulloa-Chacón, 2003), particularly in tropical islands (Wetterer et al., 2016). It is important to state that although this species was considered native in this study, it is uncertain if it this is the case for the entire Caribbean Region (Wetterer et al., 2016).

These findings indicate that exotic ant species are not always a prevalent group, in fact it has been documented that exotic species tend to thrive mainly in open, disturbed habitats (Wetterer et al., 2016). Nevertheless, with the data collected on this study it can not be establish if these exotics were limited by biological characteristics present in the invaded ant assemblage, by local 
abiotic factor or a combine effect of these two scenarios. At the local scale, previous research has stated that species' interactions and microclimate shape the composition of the Puerto Rican ant communities (Levins et al., 1973; Torres, 1984a, b). However, none of these studies were conducted on these sites, especially in Mona-one of the most isolated island within the Puerto Rican Archipelago. Interestingly, Mona exhibited the highest number of exotic ants in this study.

The findings of this research are important in two ways. Firstly, they provide at a comprehensive level, the presence and distribution of endemic, native and exotic ants species in natural protected areas in Puerto Rico. Secondly, these documentations will serve as critical baseline information for future changes on species' distribution, caused by the observed and projected impacts of climate change for Puerto Rico (PRCCC, 2013), particularly the sea level rise which will also affect the other island of the Antilles.

\section{CONCLUSIONS}

Native ants dominated in number and species richness in all the study sites. Exotic ant species were abundant in native forest while endemic were numerous in exotic wood plantations. Native and endemic ant assemblages did not seem to be affected by the forest replacement. Two native ants, Solenopsis geminata and Wasmannia auropunctata are considered two of the worst detrimental invasive species. But, while $S$ geminata was relatively abundant, $W$. auropunctata was rare in the system studied. However, this last species becomes very dominant when colonizing as an exotic invasive species.

\section{ACKNOWLEDGEMENTS}

I humbly dedicate this work to Juan A. Torres, a great ecologist who used ants as his preferred study group, greatly advancing the knowledge of this taxon in the Puerto Rican Geological Bank. In addition, I would also want to recognize Julio A. Jenaro for his continuos support and long-distance frienship. The findings and conclusions in this article are those of the author(s) and do not necessarily represent the views of the U.S. Fish and Wildlife Service.

\section{LITERATURE CITED}

Abensperg-Traun, M., and G. T. Smith. 1999. How small is to small animals? Four terrestrial arthropod species in different-sized remnant woodlands in agricultural Western Australia. Biodiversity and Conservation, 8: 709-726.

Adsersen, H. 1995. Research on Islands: classic, recent, and prospective approaches. In: Islands. Biological diversity and ecosystem function. P. Vitousek, L. L. Loope, and H. Adsersen (Eds.), pp.7-21. Ecological Studies, vol. 115. Springer-Verlag Heidelberg, New York.

Adsersen, H. 1989. The rare plants of the Galápagos Islands and their conservation. Biological Conservation, 47: 49-77.

Ambio. 1981. The Caribbean, 10: 274-346.

Armbrecht, I. and P. Ulloa-Chacón. 2003. The little fire ant Wasmannia auropunctata (Roger) (Hymenoptera: Formicidae) as a diversity indicator of ants in tropical dry forest fragments of Colombia. Environmental, Entomology, 32: 542-547. 
Beal, E. W. 1984. Bray-Curtis Ordination: an effective strategy for analysis of multivariate ecological data. In Advances in ecological research, 14: 1-55. A. McFadye and E. D. Ford (Eds.), Academic Press, London, UK.

Beisner, B. E., J. Hovius, A. Hayward, J. Kolasa, and T. N. Romanuk. 2006. Biological Invasions, 8: 655-664.

Birdsey, R. A., and P. L. Weaver. 1982. The forest resources of Puerto Rico. USDA. Southern Forest Experimental Station, pp. 3-10. Resource Bulletin SO-85.

Blackburn, T. M., P. Cassey, and R. P. Duncan. 2004. Avian extinction and mammalian introductions on oceanic islands. Science, 305: 1955-1958.

Bray, J. R., and J. T. Curtis. 1957. An ordination of the upland forest communities of southern Wisconsin. Ecological Monograph, 50: 131-151.

Brühl, C. A., E. Thomas, and K. E. Linsenmair. 2003. Size does matter - effects of tropical rainforest fragmentation on the litter ant community in Sabah, Malaysia. Boiodiversity and Conservation, 12: 1371-1389.

Callaway, R. M., and E. T. Aschehoug. 2000. Invasive plants versus their new and old neighbors: a mechanism for exotic invasions. Science, 290: 521-523.

Cincotta, R. P., and R. Engelman. 2000. Nature's place: human population and the future of biological diversity. Population Action International., 23-25. Washington, D. C. USA.

Cintron, B., and L. Rogers. 1991. Plant communities of Mona Island. Acta Cientifica, 5: 10-64.

Clark, D. B., C. Guayasamin, O. Pazmino, C. Donoso, and Y. de Villacis. 1982. The tramp ants Wasmannia auropunctata: autoecology and effects on ant diversity and distribution on Santa Cruz Island, Galápagos. Biotropica, 14: 196-207.

Collazo, J. A., and G. I. Bonilla Martínez. 1988. Comparación de la riqueza de aves entre plantaciones de pino hondureño (Pinus caribaea) y áreas de bosque nativo en el Bosque Estatal de Carite, Cayey, Puerto Rico. Caribbean Journal of Science, 24: 1-10.

Dalzochio, M.S., E. Perico, S. Renner, and G. Sahlen. 2018. Effect of tree plantations on the functional composition of Odonata species in the highlands of southern, Brazil. Hydrobiologia, 808: 283-300.

Department of Natural Resources. 1974. The Plan for the Management of Carite State Forest. 4-6. San Juan PR. 67 P.

Ewel, J. J., and J. L. Whitmore. 1973. The ecological life zones of Puerto Rico and the U.S. Virgin Islands, pp. 3-10. USDA Forest Service Institute of Tropical Forestry. Research Publication ITF-18.

Folgarait, PJ. 1998. Ant biodiversity and its relationship to ecosystem functioning: a review. Biodiversity and Conservation, 7: 1221-1244.

Fordham, D. A. and B. W. Brook. 2010. Why tropical island endemics are acutely susceptible to global change. Biodiversity Conservation, 19: 329-342.

Foufopoulos, J. and Anthony R. Ives. 1999. Reptile Extinctions on Land-Bridge Islands: LifeHistory Attributes and Vulnerability to Extinction. The American Naturalist, 153: 1-25. 
Gajraj, A. M. 1981. Threats to the terrestrial resources of the Caribbean. Ambio, 10: 307-311.

Gallardo, B., D. C. Aldridge, P. Gonzalez-Moreno, J. Perg, M. Pizarro, P. Pysek, W. Thuiller, C. Yesson, and M. Vila. 2017. Protected areas offer refuge from invasive species spreading under climate change. Global Change Biology, 23: 5331-5343.

Heany, L. R. 1986. Biogeography of mammals in SE Asia-estimate rates of colonization, extinction and speciation. Biological Journal of the Linnean Society, 28: 127-165.

Hoffmann, B. D., A. N. Andersen, and G. J. E. Hill. 1999. Impact of an introduced ant on native rain forest invertebrates: Pheidole megacepala in monsoonal Australia. Oecologia, 120: 595-604.

Hölldobler, B., and E. O. Wilson. 1990. The Ants. Belknap Press, pp. 378-415. Harvard University. Cambridge, Mass.

Hollway, D. A. 1998. Effect of Argentine ant invasions on ground-dwelling arthropods in northern California riparian woodlands. Oecologia, 116: 252-258.

Hollway, D. A., L. Lach, A. V. Suarez, N. D. Tsutsui, and T. J. Case. 2002a. The causes and consequences of ant invasions. Annual Review of Ecology and. Systematics, 33: 181-233.

Hollway, D. A., A.V. Suarez and T. J. Case. 2002b. Role of abiotic factors in governing susceptibility to invasion: A test with argentine ants. Ecology, 83: 1610-1619.

Krebs, C. J. 1989. Ecological methodology. Harper and Row, New York, 404 pp.

Levins, R., M. L. Pressick, and H. Heatwole. 1973. Coexistence pattern in insular ants. American Scientist, 61: 463-472.

Lubin, Y. D. 1984. Changes in the native fauna of the Galápagos Islands following invasion by the little red fire ant, Wasmannia auropunctata. Biological Journal of the Linnean Society, 21: $229-242$.

Lugo, A. E., J. F. Colón, and F. N. Scatena. 1999. The Caribbean. In North American terrestrial vegetation. Second Edition. M. G. Barbour and W. D. Billings (Eds.), pp. 34-37. Cambridge University Press. Massachussets. USA.

Martin, P. H., C. D. Canham, and P. L. Marks. 2009. Why forests appear resistant to exotic plant invasions: intentional introductions, stand dynamics, and the role of shade tolerance. Frontiers in Ecology and the Environment, 7: 142-149.

McCune, B., and J. B. Grace. 2002. Analysis of ecological communities. MJM software design, Gleneden Beach, OR. USA www.pcord.com.

Myers, N. 1989. A major extinction spasm: predictable and inevitable? In Conservation for the Twenty-first Century. D. Western and M. C. Pearl (Eds.), pp.42-49. Oxford University Press. New York, USA.

Myers, N., R. A. Mittermeier, C. G. Mittermeier, G. A. B. da Fonseca, and J. Kent. 2000. Biodiversty hotspots for conservation priorities. Nature, 403: 853-858.

Passera, L. 1994. Characteristics of tramp species. In Exotic ants:biology impact, and control of introduced species. D. F. Williams (ed.), pp. 23-43. Boulder Colorado West View. 
Pimentel, D., L. Lach, R. Zuñiga, and D. Morrison. 2000. Environmental and economic costs of nonindigenous species in the United States. Bioscience, 50: 53-65.

Platnick, N. I. 1992. Patterns of biodiversity. In Systematics, ecology and the biodiversity crisis. N. Eldredge (ed.), pp. 15-24. Columbia University Press. New York.

Porter, S. D., and D. A. Savignano. 1990. Invasion of polygyne fire ants decimates native ants and disrupts arthropod community. Ecology, 71: 2095-2106.

Puerto Rico Climate Change Council (PRCCC) working Group 1. 2013. Geophysical and Chemical Scientific Knowledge. WG1, 21-84. In Puerto Rico State of the Climate 20102013. Assessing Puerto Rico's Social-Ecological Vulnerabilities in a Changing Climate. Eds. Jacobs, K. R., A. Terando, E. Diaz. Puerto Rico Coastal Zone Management Program, Department of Natural and Environmental Resources, NOAA Office of Ocean and Coastal Resource Management. San Juan P.R.

Renner, S., E. Périco, and G. Sahlén. 2016. Effects of exotic tree plantations on the richness of dragonflies (Odonata) in Atlantic Forest, Rio Grande do Sul, Brazil. International Journal of odonatology, 19: 207-219.

Sanders, N. J., and K. E. Barton. 2001. Long-term dynamics of the distribution of the invasive Argentine ant, Linepithema humile, and native ant taxa in northern California. Oecologia, 127: $123-130$.

Sadler, J. P. 1999. Biodiversity on oceanic islands: a palaeoecological assessment. Journal of Biogeography, 26: 75-87.

Siemann, E., and W. E. Rogers. 2001. Genetic differences in growth of an invasive tree species. Ecology Letters, 4: 514-518.

Silva-Taboada, G. 1992. The conservation of animal diversity in Cuba. In Systematics, ecology and the biodiversity crisis. N. Eldredge (ed.), pp. 169-177. Columbia University Press. New York.

Simberloff, D. 1995. Why do introduced species appear to devastate islands more than mainland areas? Pacific Science, 49: 87-97.

Sodhi, N. S., L. P. Koh., and B. W. Brook. 2004. Southeast Asian biodiversity:an impeding disaster. Trend in Ecology and Evolution, 19: 654-660.

Suárez, A. V., D. T. Bolger, and T. J. Case. 1998. Effects of fragmentation and invasion on native ant communities in coastal southern California. Ecology, 79: 2041-2056.

SPSS, 1999. SPSS advanced models manual version 9.0. Chicago, SPSS Inc.

Torres, J. A. 1984a. Diversity and distribution of ant communities in Puerto Rico. Biotropica, 16: 296-303.

Torres, J. A. 1984b. Niches and coexistence of ant communities in Puerto Rico: repeated patterns. Biotropica, 16: 284-295.

Vitousek, P. M., H. Adsersen, and L. L. Loope. 1995. In Islands. Biological diversity and ecosystem function. P. Vitousek, L. L. Loope, and H. Adsersen (Eds.), pp.1-4. Ecological Studies, vol. 115. Springer-Verlag Heidelberg New York. 
Vitousek, P. M. 1988. Diversity and biological invasions of oceanic islands. In Biodiversity. E. O. Wilson (ed), pp. 181-189. National Academy Press. Washington, D.C.

Wadsworth, F. H. 1973. The historical resources of Mona Island. In Mona and Monito-An assessment of the natural resources, pp. 1-37. ELA de PR., Office of the Governor, Vol. II. Appendix N.

Wadsworth, F. H. 1990. Plantaciones forestales en el Bosque Estatal de Guánica. Acta Científica, 4: 61-68.

Wagner, D. L., and R. G. Van Driesche. 2010. Threats posed to rare or endangered insects by invasions of nonnative species. Annual Review of Entomology, 55: 547-568.

Walker, B., and W. Steffen. 1997. An overview of the implications of global change for natural and managed terrestrial ecosystems. Conservation Ecology, 1: http:/www.consecol.org/ vol1/iss2/art2.

Wetterer, J. K., D. Lubertazzi, J. D. Rana, and E. O. Wilson. 2016. Ants of Barbados (Hymenoptera, Formicidae). Breviora, 548: 1-34.

Wetzel, F. T., H. Beissman, D. J. Penn, and W. Jetz. 2013. Vulnerability of terrestrial island vertebrates to projected sea-level rise. Global Change Biology, 19: 2058-2070.

Wiley, J., and J. Vilella. 1998. Caribbean islands. In Status and trends of the nation's biological resources. M. J. Mac, P. A. Opler, C. E. Puckett, and P. D. Doran. 2 vol., pp. 103-105. U.S. Department of Interior. U. S. Geological Survey, Reston V.A., 964 pp.

Williams, D. F. 1994. Exotic ants: biology impact, and control of introduced species. Westview Press, Boulder, Colorado.

Williamson, M. 1989. Natural extinction on islands. Philosophical Transactions of the Royal Society of London Series B, 325: 457-468.

Wojcik, D. P., C. R. Allen, R. J. Brenner, E. A. Forys, D. P. Jouvenaz, and R. S. Lutz. 2001. Red imported fire ants: Impact on biodiversity. American Entomologist, 47: 16-23.

[Recibido: 14 de agosto, 2018. Aceptado para publicación: 7 de diciembre, 2018] 